\title{
RANCANG BANGUN SISTEM MONITORING PINTU GUDANG PT XYZ BERBASIS ANDROID MENGGUNAKAN PERANGKAT SIM800L DAN MIKROKONTROLER AT MEGA 328P
}

\author{
Reza Fahyurisandi \\ Jurusan Teknik Informatika dan Komputer \\ Politeknik Negeri Jakarta \\ Depok, Indonesia \\ reza.fahyurisandi.tik16@mhsw.pnj.ac.id
}

\begin{abstract}
Abstrak
PT XYZ merupakan perusahaan yang bergerak di bidang logistik, mempunyai sebuah gudang yang berfungsi untuk menyimpan barang perusahaan. Pada pengecekan gudang sering terjadi kehilangan barang yang tidak diketahui penyebabnya yang akan merugikan pihak perusahaan. Padahal pintu gudang hanya dapat diakses oleh pengelola gudang. Untuk mengatasi masalah itu dibuat sistem monitoring pintu gudang. Sistem monitoring ini akan memberikan informasi mengenai waktu kapan pintu tersebut terbuka maupun tertutup kembali. Pembuatan sistem ini menggunakan SIM800L, AT Mega 328P, dan Reed Switch. Reed Switch merekam aktifitas pintu gudang. Informasi aktifitas pintu gudang tersebut akan disimpan di memori AT Mega 328P dan dikirim ke server melalui SIM800L. Aplikasi android menerima informasi aktifitas dari server. Informasi yang terekam dari aktifitas pintu ini akan terlihat melalui aplikasi berbasis android yang terinstal di ponsel pengguna. Dengan bantuan aplikasi berbasis android yang sudah terinstal maka pihak perusahaan dapat mengetahui aktifitas yang terjadi di gudang. Aktifitas yang terjadi akan tampil pada aplikasi dengan informasi tanggal dan waktu yang terekam.
\end{abstract}

Kata kunci : Sistem Monitoring, Aplikasi Android, AT Mega 328P, SIM800L, Reed Switch

\section{PENDAHULUAN}

PT XYZ merupakan perusahaan yang bergerak di bidang logistik, mempunyai sebuah gudang yang berfungsi untuk menyimpan barang perusahaan. Pada PT XYZ terdapat pintu gudang yang hanya terbuka ketika ada kegiatan bongkar muat barang logistik. Kegiatan ini berlangsung setiap seminggu sekali, barang yang terdapat di gudang akan diperiksa oleh pengelola gudang. Pada pengecekan sering terjadi kehilangan barang yang tidak diketahui penyebabnya yang akan merugikan pihak perusahaan. Padahal pintu gudang hanya dapat diakses oleh pengelola gudang. Terkait hal ini perusahaan ingin mengetahui apakah ada aktifitas yang mencurigakan di gudang yang menyebabkan barang dalam gudang menghilang. Untuk mengetahui hal tersebut pihak perusahaan perlu mendapatkan data dari aktifitas pintu gudang.

Oleh karena itu, PT Konekthing Benda Pintar akan membuat sistem monitoring pintu gudang. Sistem monitoring ini akan memberikan informasi mengenai waktu kapan pintu tersebut terbuka maupun tertutup kembali. Informasi yang terekam dari aktifitas pintu ini akan terlihat melalui aplikasi berbasis android yang terinstal di ponsel pengguna atau dalam hal ini adalah pihak yang bertanggung jawab dalam persediaan gudang. Dengan bantuan aplikasi berbasis android yang sudah terinstal maka pihak 
perusahaan dapat mengetahui aktifitas yang terjadi di gudang, sehingga jika terjadi pengurangan terhadap persedian barang maka pihak perusahan dapat dengan mudah menelusuri apakah barang yang terdapat di gudang tersebut hilang karena aktifitas operasi perusahaan atau karena hilang akibat pencurian dan kegiatan lainnya. Kegiatan ini dapat dilakukan dengan cara menelusuri kembali tanggal dan waktu yang terekam di aplikasi berbasis android dengan mudah.

\section{TINJAUAN PUSTAKA}

\section{A. Sistem Monitoring}

Monitoring adalah pemantauan yang dapat dijelaskan sebagai kesadaran tentang apa yang ingin diketahui. Pemantauan berkadar tingkat tinggi dilakukan agar dapat membuat pengukuran melalui waktu yang menunjukkan pergerakan ke arah tujuan atau menjauh dari itu. Monitoring juga merupakan penilaian yang terus menerus terhadap fungsi kegiatan-kegiatan proyek di dalam konteks jadwal-jadwal pelaksanaan dan terhadap penggunaan inputinput proyek oleh kelompok sasaran di dalam konteks harapan-harapan [1].

\section{B. Internet of Things (IoT)}

Internet of Things (IoT) adalah salah satu konsep yang sedang populer saat ini. Latar belakang dari konsep IoT adalah bagaimana setiap objek atau benda dalam kehidupan sehari-hari dapat terhubung ke jaringan internet. Dimana objek atau benda tersebut dapat mengirimkan data ke internet dan dapat kita akses dari mana dan kapan saja. Hal ini juga memungkinkan objek atau benda tersebut untuk bisa berinteraksi langsung dengan benda-benda lainnya. Istilah ini dikenal juga dengan komunikasi mesin dengan mesin (M2M) [2].

\section{AT Mega 328P}

AT Mega 328P adalah mikrokontroler keluaran Atmel yang merupakan anggota dari keluarga AVR 8-bit. Mikrokontroler ini memiliki kapasitas flash (program memory) sebesar $32 \mathrm{~Kb}$ (32.768 bytes), memori (static RAM) $2 \mathrm{~Kb}$ (2.048 bytes), dan EEPROM (non-volatile memory) sebesar 1024 bytes. Kecepatan maksimum yang dapat dicapai adalah $20 \mathrm{MHz}$. AT Mega 328p adalah prosesor yang kaya fitur. Dalam chip yang dipaketkan dalam bentuk DIP28 ini terdapat 20 pin Input/Output (21 pin bila pin reset tidak digunakan, 23 pin bila tidak menggunakan oskilator eksternal), dengan 6 di antaranya dapat berfungsi sebagai pin ADC (analog-to-digital converter), dan 6 lainnya memiliki fungsi PWM (pulse width modulation) [3].

\section{Arduino IDE}

Arduino IDE adalah software yang sangat canggih ditulis dengan menggunakan Java. Menurut [4], Arduino IDE terdiri dari:

1. Editor program, sebuah window yang memungkinkan pengguna menulis dan mengedit program dalam bahasa Processing;

2. Compiler, sebuah modul yang mengubah kode program (bahasa Processing) menjadi kode biner. Bagaimanapun sebuh mikrokontroler tidak akan bisa memahami bahasa Processing. Yang bisa dipahami oleh mikrokontroler adalah kode biner. Itulah sebabnya compiler diperlukan dalam hal ini;

3. Uploader, sebuah modul yang memuat kode biner dari komputer ke dalam memori di dalam papan Arduino.

\section{E. Reed Switch}

Reed Switch adalah sensor yang berfungsi juga sebagai saklar yang aktif atau terhubung apabila di area jangkauan nya terdapat medan magnet. Medan magnet yang cukup kuat jika melalui area sekitar reed switch, maka dua buah plat yang saling berdekatan tadi akan terhubung sehingga akan memberikan rangkaian tertutup bagi rangkaian yang dipasangkan nya. Reed switch adalah salah satu jenis sensor yang sering juga digunakan pada mesin - mesin industri seperti halnya sensor photo dan sensor proximity, namun 
reed mempunyai cara kerja yang berbeda dan unik dan juga mempunyai bentuk yang cukup kecil namun rentan terhadap benturan [5].

\section{F. GSM/GPRS Module (SIM800L)}

SIM800L digunakan sebagai komunikasi data antara server dan client. SIM800L merupakan suatu model GSM (Global System for Mobile Communications) yang dapat mengakses suatu modul GSM yang dapat mengakses GPRS (General Packet Radio Service) untuk pengiriman data ke internet dengan sistem mesin dengan mesin (M2M). AT-Command yang digunakan pada SIM800L mirip dengan $A T$ Command untuk modul - modul GSM lain. Modul SIM800L memiliki dimensi yang kecil sehingga lebih cocok untuk diaplikasikan pada perancangan alat yang didesai portable. SIM800L memiliki Quad Band 850/900/1800/1900 MHz dengan dimensi kecil yaitu ukuran 15.8 x 17.8 × $2.4 \mathrm{~mm}$ dan berat 1.35g. SIM800L memiliki konsumsi daya yang rendah dengan rentang tegangan power supply $3.4-4.4 \mathrm{v}[6]$.

\section{G. Aplikasi}

Pengertian aplikasi adalah suatu bagian dari perangkat lunak yang dapat digunakan untuk menyelesaikan masalah - masalah yang khusus yang dihadapi user dengan menggunakan kemampuan komputer. Sedangkan pengertian penjualan adalah suatu proses seseorang atau organisasi untuk meyakinkan customer membeli produk yang ditawarkan [7].

\section{H. Android}

Android merupakan salah satu operasi sistem pada perangkat mobile. Dalam pengembangan aplikasi android menggunakan platform java sebagai bahasa pemrogramannya. Google bekerjasama dengan lebih dari 47 perusahaan lain yang tergabung dalam OHA yaitu (Open Handset Alliance) untuk membuat standar pada perangkat mobile [8].

\section{HASIL DAN PEMBAHASAN}

\section{A. Gambaran Umum Sistem}

Sistem monitoring pintu gudang PT BGR berbasis android dirancang untuk melakukan pemantauan pada pintu gudang secara real time untuk meminimalisir kehilangan barang di gudang dan mengetahui aktifitas pintu gudang. Sensor yang digunakan ialah reed switch. Data dari sensor akan dikirmkan ke server menggunakan SIM800L, kemudian aplikasi android akan mengambil data tersebut menggunakan link API yang telah dibuat. Data akan ditampilkan pada menu door sensor dan riwayat monitoring pintu bisa dilihat melalui menu history. Gambaran umum sistem dijelaskan pada flowchart dan blok diagram sebagai berikut:

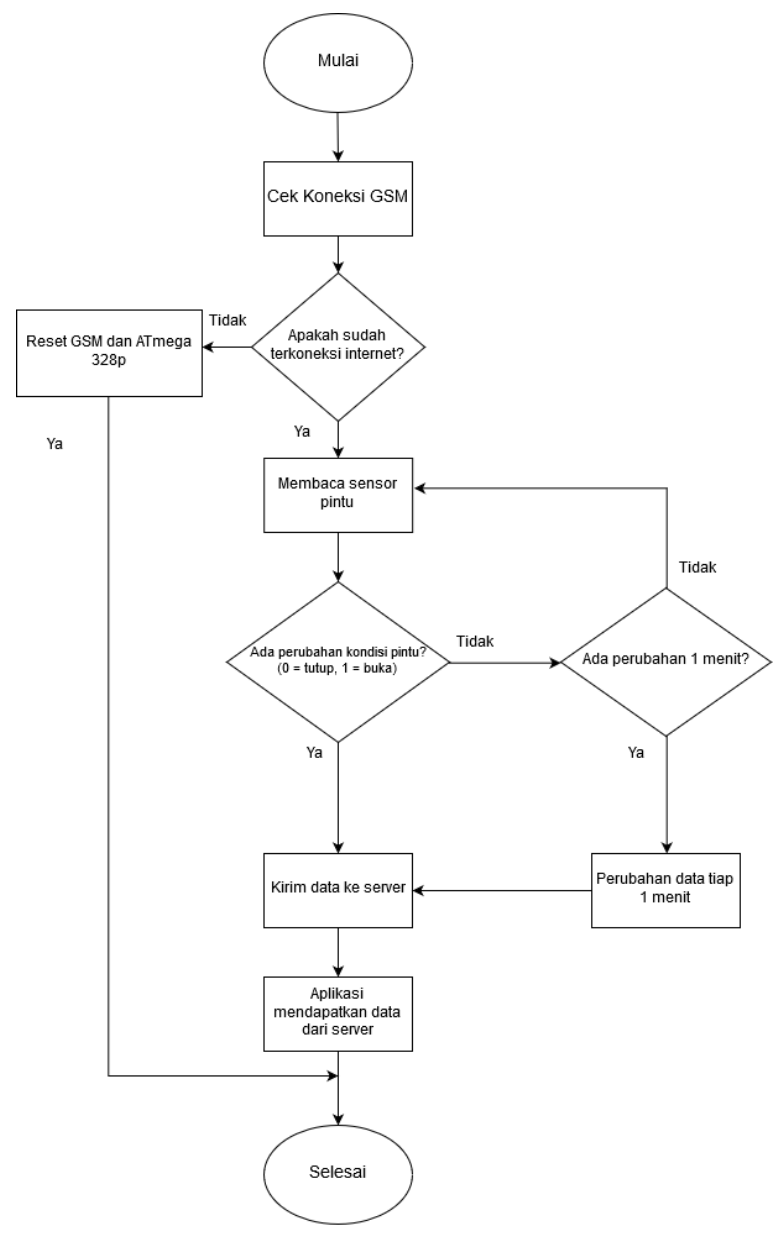

Gambar 1 Flowchart Sistem Secara Umum 


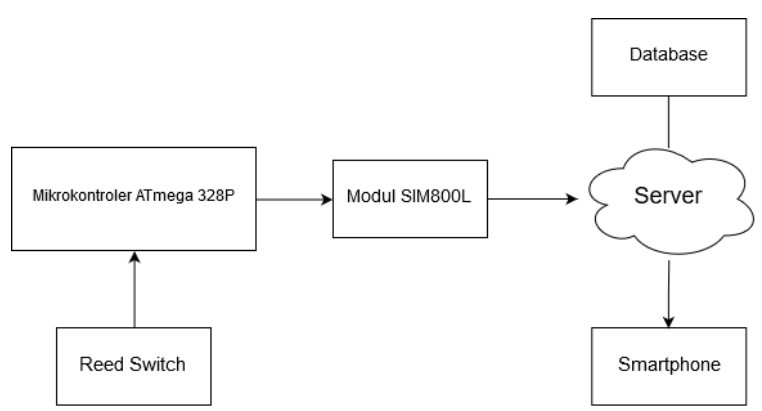

Gambar 2 Blok Diagram Sistem Secara Umum

\section{B. Perancangan PCB (Printed Circuit Board)}

Proses perancangan PCB dibagi menjadi tiga yaitu:

\section{Pembuatan layout PCB}

Layout digunakan sebagai dasar rancangan PCB sebelum dilakukan proses produksi PCB atau pembuatan PCB. Proses pembuaan layout yang pertama dilakukan ialah membuat rancangan schematic PCB. Pembuatan rancangan schematic menggunakan software Fritzing atau software yang sejenis. Penyusunan schematic PCB berdasarkan komponen apa saja yang akan saling terhubung. Komponen yang digunakan yaitu:

- Mikrokontroler AT mega 328P

- Module GSM/GPRS SIM800L

- $\operatorname{LED}(\mathrm{H})$

- Buck Converter

- Capacitor $16 \mathrm{~V} / 47 \mu \mathrm{F}$

- Capacitor nonpolar 22pF

- Capacitor $100 \mu \mathrm{F}$

- Regulator LM7805

- Reed Switch

- Crystal Osillator $16 \mathrm{MHZ}$

- Resistor 330 dan $1000 \mathrm{Ohm}$

- FTDI (Future Technology Devices International)

- Switch (Male Header)

- Power Jack
Penyusunan schematic berdasarkan hubungan antar komponen yang terpasang.

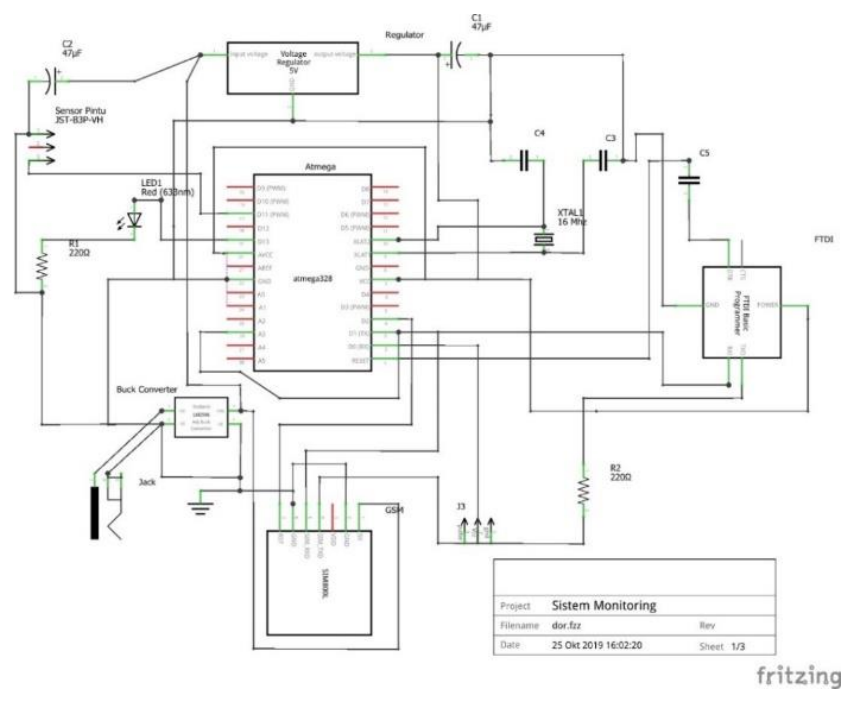

Gambar 3 Schematic PCB Sistem Monitoring

2. Proses Pembuatan

Pada proses pembuatan PCB, layout PCB yang telah jadi akan dilakukan proses sablon ke permukaan PCB kosong. Layout disablon menggunakan cara manual. Layout yang telah disablon dilakukan pengecekkan maka dilakukan proses etching (pelarutan) dengan mencelupkan PCB pada larutan Ferri Chloride. Proses tersebut dilakukan hingga PCB terlihat transparan. Setelah itu, untuk menghilangkan sisa kertas layout menggunakan cairan tinner hingga tembaga terlihat. Sebelum dipasangkan komponen pada PCB dilakukan pengecekan jalur menggunakan multimeter untuk memastikan jalur tersebut terhubung.

\section{Pemasangan komponen}

Pemasangan ini dikerjakan setelah diperiksa jalur yang ada pada PCB yakin valid dan benar. Proses awal dari pemasangan komponen yaitu melubangi titik tempat kaki komponen dengan bor. Komponen akan dipasang sesuai dengan letak komponen.

C. Pemrograman SIM800L dan Reed Switch pada Arduino IDE

Adapun konfigurasi pemrograman yang dilakukan di software Arduino IDE yaitu: 
1. Download library untuk SIM800L yaitu TinyGsm. Library didapatkan dari menu Sketch > Include Library > Manage Library atau dengan CTRL+Shift+I. Kemudian pilih install untuk download library tersebut.

2. Pada library yang digunakan diperlukan inisasi untuk memilih modem yang digunakan di SIM800L yaitu TINY_GSM_MODEM_SIM800.

3. Konfigurasi Access Point Name (APN) dan Server : SIM card yang digunakan oleh SIM800L yaitu dengan provider Telkomsel. Untuk server menggunakan ip address yang didapatkan dari divisi system admin. APN dan server yang digunakan, yaitu:

Konfigurasi APN

- APN : Internet

- Username : [kosongkan]

- Password : [kosongkan]

Konfigurasi Server

- Server : 103.229.73.25

- Resource : /tsel/server.php

4. Inisiasi pin pada SIM800L, reed switch, LED. Pada SIM800L untuk pin TX dan RX berada di pin 2. Pada reed switch terletak di pin 11 yaitu untuk pin input pullup. Kemudian pada LED terletak di pin 13.

5. Konfigurasi dalam pengiriman data sensor yang akan dikirim ke server. Inisiasi variable pada flag, timekirim, dan newdoorsensor. Pengiriman data dilakukan dengan dua kemungkinan yaitu data dikirim selama satu menit atau ketika ada perubahan pada data awal.

6. Pengiriman data ke server melalui SIM800L: Data akan langsung dikirimkan ke server ketika sensor menunjukkan dua kemungkinan yaitu data selama satu menit atau perubahan kondisi sensor. Indikator yang menujukkan data dikirim ialah LED. Jika LED blink sebanyak 5 kali menandakan data telah terkirim ke server.

7. Informasi indikator error ketika LED blink 2 kali menunjukkan bahwa SIM800L tidak mendapatkan sinyal internet. Jika LED blink
3 kali menunjukkan bahwa tidak terhubung dengan GPRS berdasarkan APN setting.

\section{Use Case Diagram aplikasi}

Use Case Diagram menggambarkan aktifitas atau interaksi yang bias dilakukan dan tidak bisa dilakukan oleh user kepada sistem.

E. Tampilan Fitur Aplikasi

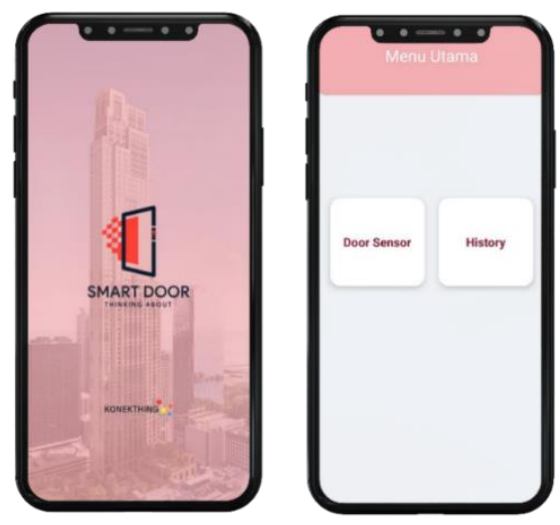

Gambar 4 Tampilan Halaman Awal dan Halaman menu

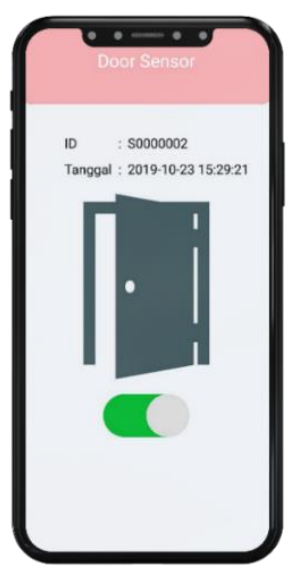

Gambar 5 Tampilan Halaman Door Sensor 


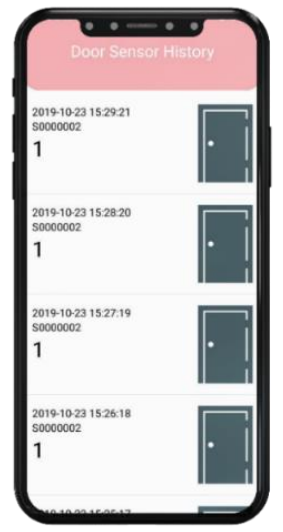

Gambar 6 Halaman History

\section{F. Hasil Pengujian Aplikasi}

Pengujian program aplikasi pada tiap menu menggunakan metode Black Box. Pengujian dilakukan pada pintu perusahaan PT Konekting Benda Pintar sebanyak 5 kali. Berdasarkan hasil pengujian yang sudah dilakukan maka kesimpulan yang dapat ditarik dari data yang didapatkan pada tiap menu yaitu:

1. Menu Door Sensor saat dilakukan pengujian untuk penerimaan data dari sensor dengan rata-rata waktu delay yang ditempuh adalah 5,6 detik.

2. Menu History saat dilakukan pengujian dalam penerimaan maksimal 1000 data dengan rata-rata waktu delay yang ditempuh adalah 1,4 detik..

\section{G. Pengujian Pengiriman Data}

Pengujian pengiriman data pada sistem monitoring pintu gudang dilakukan sebagai berikut:

1. Memastikan jika seluruh rangkaian sensor, module, dan mikrokontroler sudah benar dan sesuai dengan pin yang diinisiasi pada Arduino IDE.

2. Melakukan proses upload source code yang terdapat pada Arduino IDE menggunakan FTDI (Future Technology Devices Internasional). Hubungkan FTDI dengan konektor pada PCB dan kabel FTDI ke USB laptop / PC.

3. Selanjutnya pengujian pengiriman data sensor melalui SIM800L. Switch dipindahkan terlebih dahulu ke sebelah kanan. Dikarenakan serial yang ada di Atmega328p untuk RX dan TX hanya satu. Pastikan sim card yang ada di SIM800L memiliki paket data untuk internet. Reed switch sebagai sensor ditempelkan pada pintu gudang dengan sisi yang berbeda. Ketika indikator LED berkedip sebanyak 5 kali menandakan data sensor sukses terkirim ke server.

4. Buka aplikasi yang telah terinstal pada handphone pengguna. Lalu membuka menu door sensor untuk melihat apakah GET data dari server telah diterima. Jika data diterima maka pengiriman data berhasil dilakukan. Kondisi data sensor akan terlihat jika gambar pintu terbuka berarti data yang diterima yaitu 1 dan jika gambar pintu tertutup berarti data yang diterima yaitu 0 .

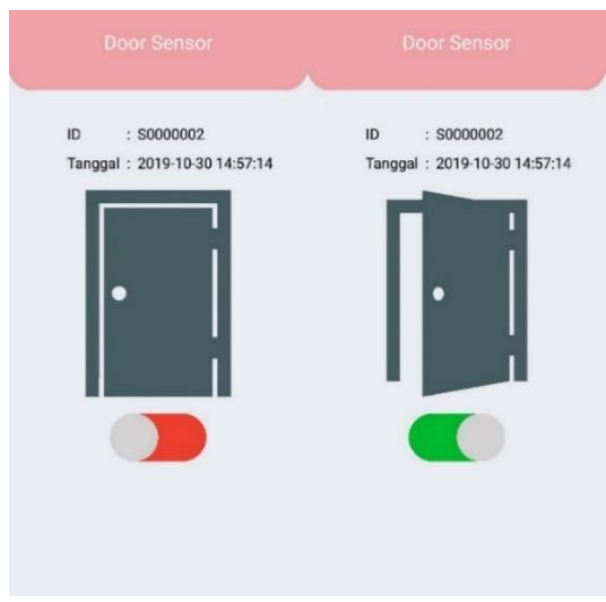

Gambar 7 GET data pada aplikasi

\section{KESIMPULAN}

Berdasarkan hasil analisis dan evaluasi yang telah dilakukan dalam pembuatan sistem monitoring pintu gudang PT XYZ berbasis android menggunakan perangkat SIM800L dan mikrokontroler AT Mega 328P, maka dihasilkan kesimpulan bahwa:

1. Sistem yang dirancang berhasil memonitor kondisi pintu gudang dalam keadaan tertututp maupun terbuka

2. Pengiriman data dari sensor menuju server berhasil dilakukan menggunakan SIM800L 
3. Menu door sensor berhasil menampilkan aktifitas, tanggal, dan waktu pintu gudang dalam rata-rata delay waktu 5,6 detik pada 5 kali pengujian. Data akan diterima dengan dua kemungkinan yaitu jika kondisi pintu berbeda dan dikirim tiap 1 menit.

4. Мепи history menampilkan maksimal 1000 data aktifitas, tanggal, dan waktu pintu gudang dalam rata-rata delay waktu 1,4 detik pada 5 kali pengujian.

\section{DAFTAR PUSTAKA}

[1] Ahsyar, T. K., \& Rahman, A. (2018). Sistem Monitoring Piutang dan Inventori Barang. 4(2).

[2] Bei, T.D.I. (2014). Universitas 17 Agustus 1945 Jakarta. E-ISSN, Jurnal Kajian Teknik Elektro, 2014(April), 2014 .

[3] Ardianto, H. (2013). Pemrograman AVR AT Mega 16. Informatika, 2, 5-18.

[4] Wahyudi, A., \& Agoes, S. (2016). Implementasi Otomatisasi Mesin Grating Menggunakan Mikrokontroler Arduino Mega 2560. Tesla. Vol. 18. No.2 . Oktober 2016, 18(2), 177-187

[5] Arafat. (2016). Sistem Pengamanan Pintu Rumah Berbasis Internet Of Things (IoT) Dengan ESP8266. Technology, 7, 262268.

[6] Affrilianto, R., Triyanto, D., \& Suhardi. (2017). Rancang Bangun Sistem Pelacak Kendaraan Bermotor Menggunakan GPS Dengan Antarmuka Website. 05(3), 1-11

[7] Ramadhan, T., \& Utomo G, V. (2014). Rancang Bangun Aplikasi Mobile Untuk. Jurnal Teknologi Informasi Dan Komunikasi, 5, 47-55.

[8] Sadewo, A. D. B., Widasari, E. R. \& Muttaqin, A. (2017) 'Perancangan Pengendali Rumah menggunakan Smartphone Android dengan Konektivitas Bluetooth'. Jurnal Pengembangan Teknologi Informasi dan Ilmu Komputer, 1(5), 415-425. 